\title{
AUTHENTIC MATERIALS FOR BIOLOGY STUDENTS: A NEED ANALYSIS IN ESP TEACHING
}

\author{
Made Aryawan Adijaya \\ Universitas Pendidikan Ganesha \\ e-mail: aryawan_aj@yahoo.com
}

\begin{abstract}
The present paper is attempting to reveal the students' need towards the authentic materials in ESP teaching at Biology Department of Ganesha Univeristy. There were 154 students taken as the subjects of the study. The primary data were gained from the responses given by the respondents through questionnaire, while the secondary data were taken from documents study on the curriculum, and syllabus of ESP, and interview in order to get the justification and clarification towards some selection on the questionnaire. The data show that the students need authentic materials such as newspaper article, scientific journal, international papers, internet, technical documents, manual, textbook, and grammar textbook. In spite of the authenticity, it is considered to able to promote students' motivation and bridging the gap between the classroom situation and real life purposes.
\end{abstract}

Keywords: authentic materials, need analysis, English for specific purposes (ESP)

\section{INTRODUCTION}

ESP program in the context of formal education ( for e.g. school) usually combines subject matter and English language teaching which highly motivates students to be able to apply what they learn in their English class to their main field of study, whether it is economics, science or tourism. The students' abilities in their subject matter fields, in turn, improve their ability to acquire English because subject matter knowledge gives them the context they need to understand the English of the classroom. In ESP class, students are shown how the subject matter content is express in English, thus helping them learn English faster

The aim of ESP course is to prepare the learners in accordance with the specific skills and vocabulary needed in their own fields. Therefore, the foundation of all ESP is related to the simple question of why the learner needs to learn a foreign language. According to Mohan (1986), in such content-based language courses, the aim is not to think the target language only as a medium of communication, but as a medium of learning across the curriculum. The language that the students use is from authentic materials of their own disciplines, so the goal of such courses is to integrate not only language learning but also content learning. Students following ESP courses become proficient in English in their own fields as the focus are on the exchange of important information, and the language use is purposeful.

In most ESP instruction practices, instructors are dependent on the materials that are available in the market. Learners are required to use the same textbook repeatedly regardless their real needs. It is common that lecturers make a convenient effort by using the available textbook and rely on to it most of the time. There is hardly effort to meet the actual needs of the learners. It potentially creates a problem on the students' motivation in learning English ( Graves, 1996)

For some lecturers, they tend to select their teaching materials that are based on their availability. Sysoyev (2000) states that chosen materials determine the content of the course. It sometimes serves as a justification and 
explanation of the use of the same syllabus with different students. In student-centered instruction, the appropriateness of materials includes student comfort and familiarity with the material, language level, interest, and relevance. However, Johns and Dudley-Evans (1991) states that one of the core dilemmas ESP lecturers find themselves in a situation where they are expected to produce a course that exactly matches the needs of a group of learners, but are also expected to do so with no, or very limited, preparation time.

Using authentic materials can be an interesting option to cope with such problems stated above as lacking of students' motivation, neglecting the students' needs towards the materials, and integrating the language (English) learning and content learning. It presents good opportunities in teaching to bridge the gap between the classroom and the outside world because authentic materials are considered as appropriate means of showing the real use of English for communication rather than materials which were designed specifically for teaching purposes. (Guariento \& Morley, 2001).

The author observed that ESP program at Biology Department of Ganesha University is designed and categorized into workmanship skilled courses (Mata Kuliah Keahlian Berkarya/MKB) and was scheduled for two semesters (first and second semesters), with two credit points for each semester. The students are expected to be skillful and professional in their own discipline with good English mastery. This requires collaboration by combining the aspects of occupational context, academic skills, and general English.

In the case of ESP program in Biology Department of Undiksha, the materials designed by the lecturers did not meet the real needs of the students. This is the reason why a need analysis about the materials needs to be conducted in order to get a balance between what the students' need and the reality.

\section{METHODS}

This study is a descriptive qualitative research since it only describes the students' needs about the materials on ESP program at
Biology department of Ganesha University. The subjects of this study were taken by census since it involved all the elements in the population (Sugiyono, 2009). So all of Biology Department students of Undiksha Singaraja became the subjects of the study, with the total number of the subjects of the study was 154 . The qualitative data were primarily gained from the responses given by the students through questionnaires. While the secondary data were collected through interview to get justification and clarification towards some selection on the questionnaire, and documents study on the curriculum, and syllabus of ESP

\section{FINDINGS AND DISCUSSION}

Based on the university guideline study book which contains the curriculum of the overall departments of Ganesha university, ESP program is designed and categorized into workmanship skilled courses (Mata Kuliah Keahlian Berkarya/MKB). They contain some subjects that are aimed at producing skillful workers based on their basic discipline and particular skills. ESP class at Biology Department was specifically scheduled to the students for two semesters. In the first semester, the course is named with English for Biology I, it was given together with the general English and both of them have two credit points. Then, in the second semester, the students were given English for Biology II with another two credit.

Paying attention to the standard competency available in the syllabus, it is known that the students are expected to be able to apply the English functional skill ( listening, writing, reading, speaking and translation) in order to support the activity of biology learning process. That standard competency is then elaborated into four basic competencies; 1 ) to present the ability of English basic principles, 2) to present listening and reading skill, 3) to present writing and speaking skill, and 4) to present translation skill. Furthermore, the standard competency reflects the expectation of the students as it is directed by the standard competency of the outcome (students) stated in the curriculum. 
As it can be clearly seen in the output competency standard for Biology Department, there are 16 points of standards that the students have to have after they finish their study. Among those points, there are four points that have close relationship to ESP program, they are : having effective communication skills (point 6), having inquiry skill in doing the research ( point 8), being skillful in making use of information and technology and communication ( point 9), and being able to communicate and interact with other people (point 11). So it seems that ESP plays an important role to develop students' skill in both oral and written communication that involves language, either Indonesian or English.

When the respondents were asked about the learning materials, the data show that almost all students considered the materials are useful in learning English for biology. Those materials include newspaper article, scientific journal, international papers, internet, technical documents, manual, textbook, grammar textbook. They thought those materials are authentic that they will deal with any time during their study and in the future work later. Besides that, the presence of the cultural awareness of the target language in the newspapers, for example, can raise the students' interest and curiosity in learning. This situation is supported by Richard (2004), who stated that authentic materials offer high value due to their relevance to the real word because they are helped to enrich their own experience in the learning and the use of English, and to generate a learning strategy for learning not only English but also the subject matters.

The students also felt motivated by being provided with some selections of authentic materials because they are not exposed with anything beyond their imagination. In some published textbook, for example, they present some illustration of manual or any other technical documents which are designed specifically for teaching purposes with complex grammatical rules. It did not help them to have the real and valuable language input that they need for current goals of learning and work field after graduation. Manual and technical documents can be directly presented to the classroom as the authentic materials, so that students will experience something real.

They see how the instruction, direction, and prohibition are expressed in English. They also know what jargons or technical terms are frequently used in those documents. The display of some colors, and pictures provide them with clues in understanding the manual. So students's motivation can be promoted by using authentic materials which extract the real information of the real text, and reflect the changes in language use, which do not occur in the published textbooks. (Berardo, 2006). Nuttal (1996) further adds that exposing the students with authentic materials provide the evidence that the language is used for real life purposes by real people and not only studied in the classroom.

Tabel 1. Students' Response towards the Learning Materials

\begin{tabular}{|c|c|c|c|}
\hline No & Learning Materials & Useful (\%) & Less Useful (\%) \\
\hline 1 & Scientific journal & 100 & 0 \\
\hline 2 & Video cassette & 98.1 & 1.9 \\
\hline 3 & Internet & 97.3 & 2.6 \\
\hline 4 & Manual & 96.8 & 3.2 \\
\hline 5 & Textbook & 96.8 & 3.2 \\
\hline 6 & Grammar textbook & 96.8 & 3.2 \\
\hline 7 & Audio cassette & 95.5 & 4.5 \\
\hline 8 & Newspaper articles & 92.9 & 7.1 \\
\hline 9 & International papers & 92.1 & 7.1 \\
\hline 10 & Technical document & 89.3 & 9.7 \\
\hline
\end{tabular}


For learners, The materials provide the basis for the content of lessons, the skills taught and the language practice activities learners take part in. The materials may be the main source of contact they have with the language apart from the lecturers. Instructional materials may take the form of printed materials, such as books and worksheets, and non-printed materials, such as audio-visual materials.

Despite the growing number of published ESP textbooks, even the textbooks which are appropriate in terms of subject matter, they may be inappropriate in terms of level, of function and of skill. Beside that, the topics and situations of the language teaching is linked to the students' subject specialism. It thus seems to be an unavoidable facet of the ESP lecturers/course directors that they should be materials writer as well since the material available in the published materials do not drive from the real world outside the language teaching classroom or the textbook writer's study, they will not help the student who wishes to use language in the real world

The authenticity of the materials serves as the basis for language input and practice for learners, and also provide the basis for the content of lessons, the skills taught and the language practice activities that the learners take part in. However, the authentic materials like newspaper article, scientific journal, international papers, internet, technical documents, manual, textbook, grammar textbook would not be interesting for the students and helped them to be more motivated in learning if they were not scientifically related to the students' discipline.

Materials for ESP and general ELT have one obvious difference. The ESP teacher will not expect to use a general coursebook organized around general human interest topics, situations, functions, etc., but will expect at least that the topics and situations that the language is linked to will relate to the students" subject specialism. Nababan (1994) states that the materials for ESP should be appropriate to the specific body of learners.
ESP materials are defined by two major factors, namely (a) the specific areas in which the language will be used, and (b) the types of learners who will be learning the language, which include their level and age, their linguistic background and educational culture. Since ESP caters for particular language needs of the students, the materials selected apply to the limited number and types of elements of the language and to the specific uses of the language.

This, of course, requires the lecturers' effort to select and modify the selected authentic materials, because the lecturers need also to pay attention to the students' interest related to the subjects of Biology that they were taking at that time. So the students were expected to get two things simultaneously, the knowledge of their specialism, and the English technical terms in Biology that are frequently used along their study. In other words, it can be said that besides being authentic, the materials should also be expected to be relevance to a particular group of However, the students expected to have not only scientific but also authentic materials. Authenticity was required by the students to make them closer to the objects that they would have or face in the real situation when they deal with the recent tasks/assignments or even when they would get the job.

Scientific journal was one of the scientific and authentic material that the students expected to have. Because they would be familiar with one of the sources of references that they could read. Beside that, students are able to read and appreciate the scientific journal articles because the information available in the manuscript is presented in a simple and logical manner by following the systematic approach (Subramanyam, 2013). As a consequence of it, they also got the extra knowledge about how to write articles to be proposed and published in the international scientific journal, and it must be presented in English. 
Dealing with the authenticity of the materials, Nunan (1999) states that the authentic texts are produced in the course of genuine communication. They provide the learners with opportunity to experience language as it is used beyond the classroom. The activity may be drawn form a wide variety of context, including TV and radio broadcasts, conversation, discussion and meetings of all kinds, talks and announcements. They principally require the exercise that the students can cope with the genuine communication that will face later in the real situation.

Considering that textbooks and other materials were generally prepared by the lecturers in advance of the arrival of the students, it sometimes did not meet the students' need. If the information on the needs and abilities of the students is inaccurate, then great adjustments have to be made to avoid applying inappropriate materials for the students. Moreover, the lecturers need also to complete the existing materials with the authentic ones in order the students to have the real description about what they would deal during the course or in the future.

The idea was to enable the students to have some knowledge of science (biology) and some knowledge of English. These two must be put together. Thus the lecturers should teach language and its rules along with the knowledge of science

When designing an ESP course, another issue to take into consideration is that grammatical functions, acquisition skills, terminology, specific functions of discipline content are crucial parts of the ESP course Jianjing (2007). In the meantime, general English language content should also be integrated into the course since content-related language cannot function without general English language content (Chen, 2006). Based on the professional experience developing the curriculum for Language Preparation for Employment in the Health Science, Gatehouse (2001) pointed out that when developing an ESP curriculum, three abilities need to be integrated into it for the purpose of successful communication in occupational settings. The three abilities encompass the ability to use particular jargon in specific context; to use generalized set of academic skills; and finally the ability to use everyday informal language to communicate effectively. Therefore, ESP course designers should take into account how to integrate the three abilities into the components of an ESP course.

A research conducted by Hutabarat (2008) in innovating English teaching materials for chemistry department by using academic writing modul and ESP vocabulary building found out that the students are more interested in learning the ESP materials than the conventional ones. Thus, it was stated that innovated ESP modules with Computer Assisted Instruction (CAI) improved the students motivation in learning ESP.

Additionally, Alijani (2014) conducted a research on the use of the authentic materials in listening activity of English for sixty Iranian foreign language learners in upper intermediate level. The result shows that authentic material improved the listening comprehension ability of the students and they were satisfied with the authentic material since it prepared them more to encounter with the real situation. Beside that the use of authentic materials has been proven to be beneficial for EFL classroom for the lack of the real opportunities that will be existed for learners to encountered with it while learning

According to Mohan (1986), in such content-based language courses the aim is not to think the target language only as a medium of communication, but as a medium of learning across the curriculum. The language the students use is from authentic materials from their own disciplines, so the goal of such courses is to integrate not only language learning but also content learning. Students following ESP courses become proficient in English in their own fields as the focus are on the exchange of important information, and the language use is purposeful.

Thus Mohan (1986) states that the proficiency above includes three abilities. The first ability was required in order to successfully communicate in an occupational setting is the ability to use the particular jargon characteristic 
of that specific occupational context. The second is the ability to use a more generalized set of academic skills, such as conducting research and responding to memoranda. With the health science group, this was largely related to understanding a new culture. The third is the ability to use the language of everyday informal talk to communicate effectively, regardless of occupational context. Examples of this include chatting over coffee with a colleague or responding to an informal email message.

\section{CONCLUSION}

Referring to the discussion above, it can be concluded that almost all students considered the materials are useful and needed in learning English for biology. Those materials include newspaper article, scientific journal, international papers, internet, technical documents, manual, textbook, grammar textbook. The authenticity became the main reason of the selection of those leaarning materials. It can also raise the students' interest and curiosity in learning by considering that thay have the real and valuable language input that they need for current goals of learning and work field after graduation. So students's motivation can be promoted by using authentic materials which extract the real information of the real text, and reflect the changes in language use, which do not occur in the conventional published textbooks.

It is suggested to the lecturers of English that they have to consider the students' need towards the presence of authentic materials in teaching English for Biology in order to bridge the discrepancy between the classroom situation and the outside world. In exposing the authentic materials for ESP teaching, lecturers need to make some adjustments towards the level of difficulties regarding the ability of the students, as well as the time limitation for the accomplishment of the course within semester.

\section{REEFERENCES}

Alijani, S. (2014). The Effect of Authentic vs

Non-Authentic Materials on Iranian EFL Learners' Listening Comprehension Ability. International Journal of Applied
Linguistic\&English Literature. ISSN 22003596. Vol.3 No 3; May 2014.

Berardo, S. (2006). The Use of Authentic Materials in the Teaching of Reading. The Reading Matrix, 6(2), 60-69.

Chen, Y. (2006). From Common Core to Specific. In Asian ESP Journal, Issue 1, Volume 2, 2006. Retrieved from http://www.asianesp-journal.com/June_2006_yc.php.

Gatehouse, K. (2001). Key Issues in English for Specific Purposes (ESP) Curriculum Development. The Internet TESL Journal, Vol. VII, No. 10. Retrieved November 29th, 2006 from http:// iteslj.org/

Graves, K. (1996). Teachers as course developers. England: Cambridge University Press.

Guariento, W. and Morley, J. Text and Task Authenticity in EFL classroom. ELT Journal, 55 (4).2001. 347-353.

Hutabarat, W. (2010). Pengembangan Bahan Ajar EP untuk Mahasiswa Sains FMIPA in Indonesia. Universitas Negeri Medan.

Jiajing, G. (2007). Designing an ESP course for Chinese University Students of Business. Asian ESP Journal Online, 3(1), Retrieved November 2007 from http://www.asianesp-journal.com/April_2007_gj.php.

Johns, A., \& Dudley-Evans, T. (1991). English for Specific Purposes: International in scope, specific in purpose. TESQL Quarterly, 25,297-314.

Mohan,B.,A.,..(1986).Language and context.Reading, MA:Addison-Wesley.

Nababan, P.W.J (1994). ESP Materials in A Foreign Language Situation. In khoo, $R$ 9Ed) 1994. The Practice of ESP Perspectives: Programmers and Projects. Singapore. SEAMEO 
Nunan, D. (1999). Second Language Teaching \& Learning. Heinle. Cengage learning.

Nuttal, C. (1996). Teaching Reading Skills in a Foreign Language. (New Edition). Oxford: Heinemann.

Subramangan, RV. (2013). The Art of Reading Article: Methodology and effectively. Journal of Oral and Maxillfacial Pathology. Vol.17 (1). Jan-Apr 2013.
Sugiyono. (2009). Metode Penelitian Kuantitatif dan Kualitatif. Bandung : Alfabeta.

Sysoyev. P.V. (2000). Developing an English for Specific Purposes Course Using a Learner Centered Approach; a Russian Exerience. The InternetTESL Journal Vol.VI, no 3, March 2000. http://iteslj.org/ 